\title{
Notion of multiple crisis and feminist perspectives on social contract
}

Originally published in:

Gender, work and organization, 25 (2018), 279-293

This is the peer reviewed version of the article, which has been published in final form at 10.1111/gwao.12206. This article may be used for non-commercial purposes in accordance with Wiley Terms and Conditions for Use of Self-Archived Versions. 
Adelheid Biesecker a

Uta von Winterfeld $b$, *

\section{Notion of multiple crisis and feminist perspectives on sociall contract}

a University of Bremen, Germany

b Wuppertal Institut, Germany

* Corresponding author:

Uta von Winterfeld

Wuppertal Institut für Klima, Umwelt, Energie gGmbH

Döppersberg 19

42103 Wuppertal

Germany

E-mail: uta.winterfeld@wupperinst.org

Phone: +49 202 2492-176

Fax: +49 202 2492-138

This is the author's version of a work that was accepted for publication. Changes resulting from the publishing process, such as editing, corrections and structural formatting, may not be reflected in this document. Changes may have been made to this work since it was submitted for publication. A definitive version was subsequently published in the Journal cited above. 


\begin{abstract}
The concept of multiple (economic, ecological, social and political) crisis has arisen from recent tumultuous economic events. This paper uses a feminist perspective to present the concept as a crisis of regeneration of both nature and social reproduction. We intend to go beyond multiple crisis using the notion of a new social contract, to overcome this crisis in a transformative way towards sustainability. A feminist analysis of the concept of social contract is founded on the critique of domination and is based on Carole Pateman's (1988) thesis that modern social contract is characterised by a 'separating inclusion' of women. It also refers to Val Plumwood's critique $(1991 ; 2002)$ of the separated and autonomous self which is part of all classical conceptions of social contract.
\end{abstract}

We argue that overcoming the multiple crisis requires overcoming structures of separation and re-envisioning concepts of the individual, by discussing the German example of a 'Social Contract for Sustainability' (2011). If the notion of social contract is to become a catalyst for transformation processes leading to sustainability, it cannot be overarching but has to be developed as a multitude of small new social and local contracts.

Keywords: Multiple Crisis, Social Contract, Domination, Feminist Analysis

\title{
Introduction
}

The term 'multiple crisis' makes clear that the so-called global economic or financial crisis is part of a complex and interrelated series of crises involving the ecological (climate, resources, carrying capacity), the social (welfare state and social coherence or solidarity) and the political (i.e. a state management or governance crisis, see Demirović et. al. 2011). From a feminist perspective, following the notion of multiple crisis necessarily leads to a focus on the crisis of work, in particular reproductive work (see Wichterich 2011; Bauriedl/Wichterich 2014: 9).

One approach to deal with the ecological crisis (especially climate change) has been developed in Germany and proposes 'A Social Contract for Sustainability' as a solution (A Social Contract for the Great Transformation, German Advisory Council on Global Change, WBGU, 2011). Here, the reaction to ecological or climate crisis is to construct a social contract.

Flagship Reports (WBGU 2016; WBGU 2011) and a Special Report from WBGU (2014) have opened a critical debate regarding social contract and a world citizen movement ${ }^{1}$ (e.g. Biesecker, Winterfeld 2013 and 2016, Brunnengräber 2014; Bauriedl 2015; Unmüßig 2015). Here we present key elements of the debate and the main conclusions of our own analysis.

\footnotetext{
1 'Climate protection is a task for the whole of human- kind and must be perceived and tackled as such. International climate policy and civil-society initiatives are not opposed to each other; rather, they can powerfully complement each other. A world citizen movement can show that climate protection in and with society can work and even generate economic benefits. This is the form of interaction in which global climate protection can and must succeed.' (WBGU 2014: 2)
} 
Fundamental to our argument is the Marxian critique of capitalism where people are alienated from one another and from their human nature; and where social relations between these are transformed into relations of exchange of commodities, a process which Marx calls reification. The first feminist ingredient is Carole Pateman's critical deconstruction of the classical theory of social contract (i.e. Thomas Hobbes, John Locke etc.) in her book Sexual Contract (1988). According to Pateman, the classical theory recites only half the story because the implicit sexual contract is ignored. No attention is paid to the problem of the exclusion of women from the original contract and simultaneously their incorporation into a new contractual order. The defining quality of this social contract, then, is the separating inclusion of women - it is a specificcally sexual contract. This separating inclusion comprises dualisms such as nature and society, and private and public spheres (separating women from the latter); a concept of the individual identified with a central male political actor as well as instrumentalising and objectifying women's bodies and labour. Though all people are pictured as 'naturally free and equal', contract theorists insist that men's right to dominate women has a natural basis (Pateman 1988: 41). The second feminist foundation is Val Plumwood's $(1991,2002)$ critical analysis of the human self within classical theory. In her discussion of the relation of human versus nature, she argues that the main problem lies in the concept of the human self as disconnected from nature. By focussing on domination, it becomes clear that the concept of the 'autonomous' self is interrelated with and supports the control of nature. However, the rationality of such control and domination is currently challenged by climate change and its concomitant uncertainties. Finally, our analysis is based on a feminist perspective that locates the chief cause of multiple crisis in structural separations in the economic and political system as well as the whole of society. Such structural separation is also consolidated by social contract (Biesecker, v. Winterfeld 2014).

From our domination perspective, the structure of modern capitalist societies is multifaceted. Here we refer to Nancy Fraser's new interpretation of Polanyi's concept of double movement in The Great Transformation. Polanyi analysed the development of capitalism as processes of 'dis-embedding' markets (leaving the two 'beds' of nature and of society) and of 're-embedding' them politically, and of commodification averted by social protection (Fraser 2012). Fraser puts emphasis on the structure of modern societies. Referring to Hegel's statement that the sphere of contractual relations (the market sphere) is based on non-contractual relations (the non-market sphere), she finds the roots of the capitalist crisis in ongoing 'fictitious commodification', as Polanyi called $i^{2}{ }^{2}$ of the non-market sphere by which capitalism undermines and destroys its own basis. For Fraser, it is necessary to connect 'a structural critique of fictitious commodification to a critique of domination' (Fraser 2012: 12). She criticizes Polanyi for implicitly valuing embedded markets as 'good' and dis-embedded ones as 'bad', and for not recognising that the political sphere as well as the economic sphere are realms of domination such that there are three targets for social movements: 'Not just marketization and social protection, but also emancipation' (Fraser 2012: 9). In an earlier paper she makes clear that: 'Present day critical theorists must revise this

\footnotetext{
2 Polanyi called this commodification 'fictitious' to make clear that the fundamental bases of social life, labour, land and money, cannot be commodities (which are produced for the market) and would be damaged and destroyed if they were treated as such. (Polanyi 1944, Ch. 6)
} 
framework. Avoiding both wholesale condemnation of dis-embedding and wholesale approbation of re-embedding, we must open both marketization and social protection to critical scrutiny. Exposing the normative deficits of society, as well as those of economy, we must validate struggles against domination wherever it roots'(Fraser 2011: 144). Developing a new social contract for sustainability therefore means rethinking the role of 'struggles for emancipation' (ibid.). As it is imperative that a new sexual contract is part of the new social contract, feminist struggles must be noted. Our reference to Nancy Fraser illustrates that social contracts are not only based on a particular relationships between nature and the individual, but also on the strength or weakness of emancipation struggles.

Based on the perspective of these three feminist scholars we have formulated our main argument as follows:

The core of multiple crisis as a social, ecological, economic, financial and political crisis is a regenerative or reproductive crisis. Social contract is not the solution, but part of the problem as long as it does not overcome the structure of separating inclusion and the concept of an autonomous individual or self. It thus cannot ensure gender equity.

To further clarify this central idea, we first develop our analysis of multiple crisis as regenerative or reproductive crisis. The economic structure of separation as well as the role of capital as a social power relation will be made visible. Based on Carole Pateman's work we then discuss the basic structure of the modern social contract to point to its main weakness - the 'separating inclusion' of women. Here we also refer to Val Plumwood's critique of the separated self which is part of all classical conceptions of social contract. She proposes a relational account of the human being as a foundation for a new social contract for sustainability. The relation between the transformation process and the social contract will be discussed in the last section using the example of WBGU's reports. Here we investigate ideas of man and nature, of policy and economy before presenting our conclusions.

\section{Multiple Crisis as Regenerative Crisis}

The concept of multiple crisis elucidates the broad character of the phenomenon but does not clarify its origins. In the following paragraph we try to contribute to this. Our point of departure is, following Nancy Fraser, the structure of modern capitalist economies and democracies. This structure is characterised by separation: economically distinguishing the productive and the regenerative as reproductive while politically divorcing the public (democratic) and the private (domestic) sphere.

From this structural separation follow very narrow definitions of the economy as well as of the political sphere. The economy is identified only with self-regulating markets, labour only with paid work performed to produce commodities and services. And democratic control and regulation only apply to the public sphere. The capitalist character of the economy becomes apparent not only through the guiding principle of profit maximisation, but also and foremost by the alienation of people and reification of their social relations. This is Marx's commodity fetish. Workers sell their labour power as a commodity to capitalists who control working conditions and appropriate products and profits. Thus, the workers are alienated from the products of their labour. All 
specific qualities of labour are converted into a quantitative equivalent; the value of commodities for exchange at the market. The qualitative variety of various forms of labour as well as the class relation between workers and capitalists are obscured. People are not related to each other as members of the human race and of civil society, but only as owners of commodities, only in exchange. That is the exclusive social relationship they have. The core of the commodity fetish is that the mutual relations of the producers 'take the form of a social relation between the products' (Marx 1867/1972: 86 (own translation)). Capital as a power relation seems to have disappeared. This power relation re-emerges if we consider the sphere of economic activities which is excluded from the market economy; that is the realm of the regenerative nature with its productivity, and of unpaid work. These two basic elements in every human production process are externalised. They are only regarded as being reproductive.

Though production always needs this reproductive element, this does not have value for the actors in the market economy. No human production process can happen without the previous productive input of nature and it cannot happen without previous processes of caring, mostly provided by women. Capitalist production is not possible without the exploitation of these externalised regenerative forces originating from the life-world. The same is true for the political realm as the public sphere always needs the private as its foundation, but this sphere has no voice. The consequence is the ongoing damage and destruction of the regenerative and the so called private sphere.

Rosa Luxemburg intensively discussed this dualistic structure of capitalism. For her, the externalised elements are foundational conditions for the capitalist system. She highlights the relation between the two spheres - the 'productive' and the 'reproductive' - as a relation of domination and reveals the role of political power in altering and reforming the boundaries between the two spheres. In her words, political influence is only 'a vehicle of the economic process' (Luxemburg 1913/1981: 397/98, own translation). While Rosa Luxemburg sees the dualistic structure as capitalist vs. noncapitalist, feminist theory has since made clear that the two sides of the dualism are integral parts of the capitalist system. From a feminist perspective, the process of accumulation of capital can be seen as an ongoing process of changing the boundaries between these two spheres and of redefining what is considered 'intern' and 'extern' (for an overview see Biesecker/v. Winterfeld 2014). We point to a recent example of the labour market in Germany where highly qualified women are integrated 'into the market' (e.g. the research program 'Women to the top'). This process coincides with the temporary or permanent externalisation of low-income women with no or few qualifications and of children considered impediments to the marketization of their mother's labour power. Such boundary changing processes are possible ways to overcome capitalist crisis with a new social contract for sustainability are central to our interest.

By making explicit the demarcation between 'intern' (economic and political realms) and 'extern' (reproductive and private spheres), the principle of 'identification' becomes visible. For Wolf-Dieter Narr this is the archetypal principle of domination (Narr 2015: 97). Following this, identifying the same (e.g. the occident or the political or the economic) means also identifying the other (e.g. the orient, the non-political, the noneconomic) as its shadow. At the same time, instrumentalism and objectification are 
taken into account by analysing the function of identification (as inclusion and exclusion). The capitalist economic sphere needs non-valued work and resources for new processes of evaluation; for creating value in the first place. These are appropriated instrumentally, and as invisible and silent objects.

The political sphere engages in creating a supportive environment for capitalist economic activities. Identification makes use of rhetorical figures (Hirschman 1991) by taking advantage of public myths and prejudices. In this way, repressive policies can be justified; for instance, by legitimising cuts in welfare benefits by stigmatising certain strata of the population as lazy parasites (scroungers in the UK or welfare mums in the US). The exclusion and stigmatisation of certain people as others is used in public discourse as a resource for legitimation, and as an object for anger, blaming the victim and silencing critiques of neoliberal social policies and politics. Drawing the boundaries in this way defines the 'external', the 'reproductive' and the 'regenerative' as clearly as the 'internal', the 'productive' and 'the generative'.

The phenomena associated with the ecological crisis (e.g. loss of natural productivity and of biodiversity, scarcity of food, resources and energy, climate change) are phenomena of the capitalist appropriation of nature and a consequence of the domination and control over nature. But control as a strategy is not suited to conditions of uncertainty. Indeed, there are two contradictory strategies: emergency response plans and safety precautions on the one side, and the genuine involvement of stakeholders and citizens on the other. But both strategies tend to 'forget' care and regeneration (see below).

The phenomena associated with the social crisis (e.g. lack of provision and care, welfare state crisis, the problem of overwork and low paid, flexible and reproductive work, child poverty) are phenomena of the capitalist appropriation of reproductive work as well as the political shaping of public infrastructures. In principle, the social and the ecological crisis are both crises of the regenerative sphere.

Moreover, even the financial crisis can be seen as a reproductive crisis. Here, the target of exploitation is the real economy. For instance, companies are destroyed when bought, and then sliced up and sold for short-term profits by hedge funds and other financial speculators. Speculative behaviour like this caused the debt crisis. The general conclusion to be drawn here is that there is an indissoluble friction between the profit motive and regeneration.

As a result, modern capitalist economies produce wealth and growth by systemically destroying the basic natural and social productive resources for this growth. Thus, those economies create products and processes which are inherently unsustainable. Modern State policies are concerned with either gaining or preserving power. They preoccupied narrow time frames and exclusively concerned with the support of the globalisation of their national capital, often against the public will (as recent examples see the negotiations about the free trade agreement TTIP (Transatlantic Trade and Investment Partnership) and CETA (Comprehensive Economic and Trade Agreement with Canada)). Expressions of the crisis of representation (parliamentary crises) are low voter turnouts, loss of confidence and legitimacy. Some of its consequences are nationalism, racism and the danger of a new authoritarian state, a Hobbesian 'Leviathan' (we can today observe 
such consequences in some member-states of the European Union). Therefore, economic practices and policies create non-sustainable societies. Approaches designed to resolving these problems often tend to intensify the crisis because they are based on the same rationality which caused the problems in the first place, for example the commercialisation of nature to solve the biodiversity crisis; or agro-fuels, creating a new crisis of food scarcity instead of solving gaps in energy supply and climate change; or the development of global care chains to solve the care crisis in the global north, shifting the care crisis to the bottom of the chain in the global south.

Global care chains are an element of the restructuring of gender relations which contribute to multiple crisis. According to Christa Wichterich, multiple crisis can be seen as a reconfiguration of economic gender roles under neoliberal conditions, as a new gender-related international division of labour (Wichterich 2011; Bauriedl/Wichterich 2014). The erosion of the male breadwinner model is accompanied by the growth of responsibility of women for the family income. Despite these changes, the hierarchal structure of gender relations stays intact. Wichterich distinguishes two crises in particular: the crisis of paid work, and the crisis of the care economy. Here we observe again that new boundaries and a new definition of intern and extern are drawn. The crisis of paid work is characterised by a reduction of the availability of normal employment and by a growth of informal and non-permanent labour contracts. Wichterich calls this the 'feminisation of paid work' (Wichterich 2011: 133, own translation). Precarious work, in which 52 per cent of women are engaged, and the growth of the working poor, of which 60 per cent are women, are symptoms of this specific crisis. This means that the increase in female labour force participation does not mean emancipation but integration under the ever worsening conditions of the capitalist labour market. The crisis of the care economy is, especially in the global north, based on the public debt crisis. This leads to privatisation with a consequential shift of public and paid care work towards more unpaid care work for women. In the global context, the crisis of care work finds its expression, as already mentioned, in global carechains, leading to a global shift of care work from south to north and from east to west (compare Ehrenreich; Hochschild 2002). This does not mean a redistribution of care work between the genders but only between women in high- and low-income countries. Current calls to increase the proportion of women in leading economic positions in Western European countries are based on this new line between intern and extern.

\section{What's Wrong with the Social Contract? - What's Wrong with the Individual?}

A society with an economic and a political system systemically leading to nonsustainability must be founded on the wrong set of constitutional principles. In the history of political thought such principles are grounded in what has been termed a social contract (Reitzig 2005). Therefore we ask: what is wrong with the current contract? To answer this question, we draw on critiques by Carol Pateman. As we will see, the ways in which social contract has been delineated in the $17^{\text {th }}$ century (in particular by Thomas Hobbes and John Locke) are all based on very specific views of nature and man, and the relation between them. The latter is the main focus of Val Plumwood's academic work. Referring to her concept of the self-in-relationship 
(Plumwood 1992), we discuss this specific approach to the individual combined with a variety of conceptions of social contract, and with the prospect of a sustainable future.

\section{What's Wrong with the Social Contract?}

In the 1980s, Carole Pateman presented her analysis of social contract (in particular those of the $17^{\text {th }}$ century) as a sexual contract (Pateman 1988). Contemporary contractual theory has been formulated first by John Rawls in the 1970s in his influential theory of justice within the framework of political social contract theory (Rawls 1971). Quite recently, the WBGU has begun to argue that sustainability and sustainable transformation need to be founded on a new social contract (see WBGU 2011). However, a broader view of the origins of multiple crisis and the present-day debate about a new social contract have to reflect the structure of social contract and have to ask: what is a social contract? And, why do we need it?

The story of social contract tells us how a new civil society and a new form of political rights and political order are created through an original constitutional agreement. This original contract is a fiction (contract theory). It is situated at a supposed threshold where humans move from 'state of nature' to being part of a 'civil society'. Each theorist has a particular concept of the state of nature which corresponds to his idea of civil society, including a particular view of the human individual.

For Thomas Hobbes the state of nature is a state of war - each against the other - that calls for a strong state: the Leviathan. According to John Locke, the state of nature is a state of peace. Nature is a God's gift and common property. But this state of nature is without progress. If people want to live comfortably, they need private property. Today, contract theory is about justice (John Rawls) and about transformation: sustainable transformation needs a new social contract (WBGU).

By criticising their implicit domination perspective, Carole Pateman's analysis points to important problems with these contractarian positions, as men's freedom and women's subjugation are both created by the original contract (Pateman 1988: 2). It establishes men's political right over women - and also a sexual right, in the sense of establishing orderly access by men to women's bodies (ibid). In Pateman's view, patriarchal civil society is divided into two spheres. But the story only relates the creation of the public sphere and of civil freedom. The other, the private sphere, is not considered as politically relevant (ibid: 3). Pateman argues that the subject of all contract theories is a specific kind of property: individuals are defined as owners of their personal traits (body, mind, talents etc.). But only masculine beings are endowed with the attributes and capacities necessary to enter into contracts - only men are individuals (ibid: 5 and 6). For example, John Locke argues that every man has ownership of himself as a person. Following Pateman further, the contract always generates political rights in the form of relations of domination and subordination (ibid: 8). The order of the natural (natural state) excludes the civil and vice versa (ibid: 11). Here again the principle of identification - of inclusion and exclusion - is applied. But Pateman also makes clear that the story has further complications: Women are excluded from the original contract but still incorporated into the new order. Women have no part in the original contract, but they are not left out in the state of nature. The private sphere is part of civil society but is separated from the civil sphere. The private womanly sphere (natural) and the 
public male sphere (civil) are opposed but derive their meaning from each other. This separating inclusion is essential, because the formation of what civil society with its new political order is, needs the counterpart of what it is not. What it means to be an individual, a party to contracts and civilly free, is constituted in contrast to the subjugation of women within the private sphere (ibid: 11).

The whole story of social contract expresses a specific, masculine creative power, the capacity to generate, to give birth to new forms of political life (ibid: 220). At this point we find another reason for the regenerative crisis, as the masculine is understood as homo faber; as a generating individual, in neglect of regeneration and in separation from the regenerative sphere. Freedom as guaranteed by social contract is enjoyed by all individuals. But a curious and ambivalent message is sent out to women, who represent everything the individual is not. The individual is constructed as a male body so that its identity is always masculine (ibid: 221, 223). Recently it was Joan Tronto who made clear that this male freedom includes being excepted from caring activities. 'Men don't care because ...they are given a "pass" out of what we normally regard a caring responsibilities because of two other forms of contributions they make to society... I call these passes "protection" and "production"'. (Tronto 2013: 70) This freedom, Tronto points out, 'means not having to care.' (ibid.: 92)

In this context, Carole Pateman criticises the version of the state of nature within the theory of justice of John Rawls. Rawls constructs a 'veil of ignorance' to represent the state of nature. Nobody knows his own situation and position, but everybody wants to have as good a life as possible, whether rich or poor. Because individuals are thought to be alone (similar to homo oeconomicus in economic theories), they cannot rely on the support of others. Thus the contract has to make sure that the situation and position of the weakest members of society are acceptable and fair. A social contract of justice emerges where justice means the fair distribution of chances for a good life. But: 'In effect, as Rawls' version of the state of nature shows, there is only one individual, duplicated endlessly. How the duplication takes place is a mystery' (Pateman 1988: 223). Therefore, the individual conceived by John Rawls as male shows that it is part of the sexual contract. Compared with Rawls' model the concept of social contract described by the German Advisory Council on Global Change (WBGU) is less 'individualistic' as the Advisory Council does not recognise individuals but only 'agents' (as 'change agents'). Here, individuals are designed within a transformative frame but without qualities and it is this that has prompted a debate on the WBGU's concept of citizenship (see below).

Following Pateman, the meaning of the individual remains intact only as long as the contractual order with its implicit sexual contract remains intact. If men's mastery is to be replaced by the mutual autonomy of women and men, individual freedom must be limited by the structure of social relations in which freedom inheres (ibid: 232). When the repressed story of political genesis is brought to the surface the political landscape can never look the same again (ibid: 233). Carole Pateman's conclusion, therefore, is unequivocal: 'A free social order cannot be a contractual order' (ibid). This would undermine all suggestions of a new social contract (for sustainability or for sustainable transformation) as unavoidably contaminated by domination as social contract appears indeed to be part of the problem, and not a solution to multiple crisis as regenerative crisis. Pateman makes two further arguments which support this conclusion. 
Firstly, a flaw is that the men who agree to the original contract are white men. Therefore, their fraternal pact is a social contract, a sexual contract and a slave contract (legitimising the rule of white over black) (ibid: 222). The second of Pateman's arguments is based on a critique of Hegel's philosophy of right. Following her analysis, he criticises Jean-Jacques Rousseau's social contract theory and Immanuel Kant's marriage contract. But Hegel also claims that women are naturally lacking in the capacity to submit to the demands of universality' (ibid: 176). Starting from his natural difference principle, Pateman reconstructs Hegel's point of view: 'Women are what they are by nature; men must create themselves and public life, and they are endowed with the masculine capacity to do so' (ibid) - women are connected with 'nature' and men with 'reason'. Finally, nature is not only represented by women but also, for example, by land, indigenous peoples, the descendants of slaves and animals (ibid: 226). Pateman's analysis is not just historical. It does not only reveal a phenomenon of the past century. She argues that the simultaneous denial and affirmation of the freedom of women fostered by contract theorists, is continually reconstructed because freedom as autonomy is still coupled with sexual domination (ibid: 230). The fifth chapter of The Sexual Contract illustrates the importance of this analysis. The chapter is 'Wives, Slaves and Wage Slaves' (ibid: 116f); here the labour contract and the marriage contract are analysed together. The necessary subsistence to maintain children is provided by the father and his family wage. The mother's labour is seen as "raw material" on which economic forces act and their labour is treated as elements of nature on which human (civil) society is built. Though most working-class families (and currently middle-class families increasingly face this too) have been, and are unable to survive on the husband's wage alone, women's earnings have been and are regarded as a 'supplement' to a husband's wage and they are paid less than men (ibid: 138). There is a double invisibility of women's work - in the labour market and at home.

Today the problem is not only that the capitalist market is patriarchal and structured by the sexual division of labour and that 'wives' perform valuable tasks for which they are not paid. The problem is also that separating inclusion means an ongoing externalisation as a matter of principle. New 'efficient' organisation and management systems intensify daily work and externalise all elements beyond this rationality; elements of care, of providence, of sympathy and of reflection. The investigative German journalist Günter Wallraff recently edited a book about those who bear the load (Wallraff 2014) of this new and 'flexible work'. The report points to the physical and mental breakdown of employees as a consequence of the maximum efficiency and utility extracted from them. Therefore, the efficient management of work is part of, and intensifies the crisis as a regenerative crisis (see also Wichterich, 2011, outlined above, Atewologun, Sealy and Vinnicombe 2016).

At this point, we are still unsure whether we should accept Pateman's conclusion that a free social order cannot be a contractual order. To further develop our position we formulate three questions for consideration in developing contemporary approaches to building a social contract for sustainability:

What about the idea of man - is it still an idea of man, an individual conceived as masculine? What about the idea of nature - is it inseparably linked to instrumentalism and objectification? What is the understanding of the economy and policy within new 
contractual approaches, and what is the relationship between the two spheres? And is there an accepted role for movements for emancipation?

\section{What's Wrong with the Individual?}

To answer our third question, we can draw on the work of Nancy Fraser and our analysis of the capitalist structure as outlined previously. The economy in such a new contractual order will integrate market and non-market spheres. Sustaining the regenerative forces of unpaid care-work will become the main target. Based on recent struggles for emancipation (such as feminist movements or unionised struggle), society develops new forms of valuation of heretofore unvalued activities and new principles of distribution of the different forms of labour. It will be the role of policy to enable, coordinate and mediate these processes and to restrict the power of old vested interests.

But questions about the concept of the individual and its relation to nature, our first and second questions, still require a response. As we have seen, social contract is deeply problematic, but the concept of the individual which underpins the contractual order is also flawed. This foundational concept for theories of social contract in the $17^{\text {th }}$ century fits with the structural dualism of capitalist societies. The individual with its defined attributes belongs to the market sphere and to the public sphere. It is characterized by masculinity, and it is disconnected from nature and from social relations. This individual is conceptualized as an autonomous self. Therefore it is incapable of participating in a cooperative way in a social movement.

The notion of social contract and the different ways in which it has been developed cannot be explained only be recourse to the concept of the individual. The concept of nature as well as social struggles for emancipation also play important roles. While social contracts have to account for the individual because of universal human rights and human capabilities (see also Martha Nussbaum and her capability approach, Nussbaum 2011), theories of social contract have conceptualised an unsocial, even an antisocial individual. This is particularly the case with the work of Thomas Hobbes who fails to recognise any intermediate power but sees only socially dispossessed individuals, fighting against each other and protected from an absolute Leviathan.

As mentioned, the economic figure of this individual is homo oeconomicus; a solitary individual, related only to the world of commodities to satisfy its wants. It maximizes its own satisfaction. To pursue this single minded goal, it acts rationally. It is dominated by the fetish character of commodities - alienated from its human nature, related to others only in a contractual manner - as a buyer or seller of commodities.

The critique of this concept of the individual, and the related concept of rationality, is at the centre of Val Plumwood's work. For her 'rationalism is the key to the connected oppression of women and nature in the West'. (Plumwood 1991: 3) The particular and the emotional are seen as enemies of this kind of rationality. Plumwood regards 'the definition of the human self as separate from nature, the connection between this and the instrumental view of nature, and broader political aspects of the critique of instrumentalism' as the overall problem (ibid: 10). Instrumental reason, she argues, perceives others only as resource. They are not valued for their own sake but for their effects in producing gratification. In her last book (Plumwood 2002) she emphasizes 
again and again that this form of rationality is highly irrational. For her, the main cause of the destruction of the natural world must be seen in the inability of those 'rational' individuals to accept nature for its own sake and not exclusively as an instrument for human life. She develops an improved concept of rationality, where rationality is not only a principle of acting and thinking, but a specific form of life: 'a matter of balance, harmony, and reconcilability among an organism's identities, faculties and ends, a harmony that has regard to the kind of being as it is' (Plumwood 2002: 67). For Plumwood, the ethical foundation for such a notion of rationality is the ethic of care:

The ethic of care and responsibility... seems to extend much less problematically to the nonhuman world than do the impersonal concepts... and it also seems capable of providing an excellent basis for the non-instrumental treatment of nature...' (Plumwood 1991: 9).

Based on these two philosophical concepts (rationality as a form of life and the ethic of care), Plumwood can formulate her alternative concept of the individual - a relational account: '... we must see human beings and their interests as essentially related and interdependent' (ibid: 20). She regards nature not as an external element but as a part of our identity. 'On this relational account, respect for the other ... is an expression of self in relationship, not egoistic self as merged with the other but self as embedded in a network of essential relationships with distinct others' (ibid.). This self in relationship is no longer characterized by masculinity, but by qualities contemporarily construed as feminine. It is capable of caring for others - for other people today as well as in the future - and of supporting nature in its multifaceted processes of regeneration. Sustainability requires such a concept of human beings and their interests as essentially related and interdependent. Self in relationship is a cooperative self and therefore capable of struggling together with others for emancipation.

\section{Consequences for the Social-Ecological Transformation Processes - Manifold Small New Social Contracts}

Now we come to our empirical example, the German approach that links the construction of a new social contract to the social-ecological transformation process. This proposal for a new social contract for sustainability is a reaction to the ecological crisis, particularly to climate change. The necessary reforms to meet this crisis are meant 'to go far beyond technological and technocratic reforms: the business of society must be founded on a new 'business basis'. This is, in fact, all about a new global social contract for a low-carbon and sustainable global economic system' (WBGU 2011: 1, emphasis in original). While recognising the fictitious nature of social contracts, the WBGU uses this as a metaphor to outline a new social order that encompasses a reconceptualization of relationships between human and nature, and of economics and politics:

The idea of a social contract takes the original concept found in the natural law theories of early modern history one step further, and today's revised edition must address four major challenges: 1 . Because of progressive economic and cultural globalisation, the nation state can no longer be considered the sole basis for the contractual relationship. Its inhabitants must responsibly take 
transnational risks and natural dangers, and the legitimate interests of 'third parties', i. e. other members of the world community, into account. 2. Traditional contract philosophy presupposed the fictitious belief that all members of a society are equal. Considering the disproportionate distribution of resources and capabilities in today's international community, we must have effective, fair global compensation mechanisms in place. 3. The natural environment should be given increased consideration when revising the social contract. 4 . The contract has to bring two important new protagonists into the equation: the self-organised civil society and the community of scientific experts.(WBGU 2011, 8)

To interrogate the transformative power for sustainability of WBGU's proposed contract and to further develop our position, we come back to our three questions for timely approaches to social contract: the concept of man, the concept of nature, and the understanding of the economic and political system as well as the role of struggles for emancipation. We start with the concept of man as it is described in the flagship report of the German Advisory Council on Global Change (WBGU).

This idea corresponds to the main concern of the Advisory Council: a climate compatible society. People are 'quite capable of reducing the degree of their own spontaneous first-tier desires (short-term preferences) in favour of second tier desires' (WBGU 2011: 80), they are capable of committing to cooperation and to develop a precautionary attitude. However, the Advisory Council has no overarching concept of man and 'homo oeconomicus' is lurking when the council explains the gap between attitude and actual behaviour: '... long-term oriented decisions are accompanied by higher costs in the short-term than exclusively short-term oriented decisions' (ibid: 78).

Overall, the flagship report does not tell us anything about actual human beings or concrete persons. There are change agents, and there are many stories about engineers, urban planners, and architects. These change agents could either be part of a resistance movement such as the Black Forest 'electricity rebels' from Schönau, enterprises such as 'Deutsche Bahn' (the German national railway company) or the large-scale, technical project 'Desertec'. Human actors remain abstract and without delineations. They are sexless transformation agents (mostly mentioned in a rhetoric of 'best-practice'), but not real people - and not individuals. These change agents are first and foremost described in an instrumental and objectifying way - only insofar as they correspond to the Advisory Council's transformation priorities. Secondly, these descriptions lack detail because the whole report is written on a very high level of abstraction. Real people in their daily life and engaged in social movements are not on the radar. Achim Brunnengräber similarly critiques the Special Report from the WBGU called 'Climate Protection as a World Citizen Movement' (WBGU 2014; see also footnote 1). Brunnengräber points out that The WBGU outlines a World Citizen Movement that has lost touch with reality, ignores real climate politics and social movements as well as growing competition and shrinking cooperation (Brunnengräber 2014). Our inference is that this kind of new social contract tends to reproduce old rationales (see also Biesecker; Winterfeld 2013 and Biesecker; Breitenbach; Winterfeld 2016).

However, we believe that this old structure could be overcome whilst integrating stories of daily life and real people, with stories of people working in the market economy and 
also of those - mainly women - who are concerned with care activities inside and outside the market. These stories are also stories of conflicts and ambivalence, of social protest and social movements which, following Nancy Fraser, often entail demands for emancipation. They can result in social change. Here, new action principles including new relations to nature and new values as well as new principles of societal order can emerge - elements for a new social contract. Because of these qualities, we use the term 'small or local new social contracts' (see also Winterfeld; Biesecker 2013) to interpret these activities. These new social contracts are not fictitious but concrete and often based on the principle of mutuality. They are locally embedded, such as the new small generation contract in Eichstetten, Germany: 'The village takes responsibility for the intergenerational contract' (see Lang; Wintergerst 2013). Small contracts like this are the humus for social change.

Our second question concerns the concept of nature. The Anthropocene provides the basis for the new social contract in the report : '...the geological age in which the detrimental effects of human actions on the environment have reached a dimension that is comparable to natural influences' (WBGU 2011: 62). This is important for emphasising the responsibility of human beings, but it is still based on a strict separation of humans from nature. Human beings influence nature - and they do this in such a way that nature as nature disappears. There is no nature then, there are only effects of human influence and action, only raw materials, nutrient cycles, resources, pollutants, energy carriers and so on. The paradoxical result of our analysis is that the idea of the Anthropocene and non-nature implies once again instrumental and objectifying attitudes. It fails to offer an alternative human and social relationship to nature, a relationship where nature is not disconnected from human beings. In social movements for sustainability we find such nature-connected individuals. They struggle to establish a new human-nature relation where nature's capability of regeneration can be supported and sustained. They are also often based locally such as, for example, the social-ecological movement of community-supported agriculture (CSA) which also includes new relationships between urban areas and the countryside. Again, we interpret these activities as an approach to small and concrete new social contracts.

Our third issue leads us back to the beginning of our article - to the concepts of the economy and of the political realm. There we have made clear that, because of the boundaries which both create and structure difference, multiple crisis is in its very core a crisis of regenerative forces - nature's ability to regenerate coupled with caring activities outside the market. Based on Marx, we have shown that the actors in the capitalist market sphere are dominated by alienation and reification. And with the help of Fraser who refers to Polanyi, we have criticised the tendency toward fictitious commodification and have highlighted the importance of struggles for emancipation and their relevance for the transformation process towards sustainability. Sustainability needs a different kind of rationality than the profit-oriented rationality of capitalism, a caring rationality with a long term perspective.

Looking at the economic concept of the German Advisory Council, we often find the expression 'precautionary principle' (e.g. WBGU 2011: 5, 95, 102, 106, 107, 271, 328). This seems to refer to a long term perspective - but neither the identification of the economy only with markets nor structural separation is challenged. The economy shall 
be transformed into a climate-friendly system - but this shall happen within the old behavioural model of profit orientation. To encourage and accelerate investments into a low-carbon future (ibid: 15/16) the Council asks for stable framework conditions for climate-friendly investments 'to raise the rate of return in investments... and to minimise the risk' (ibid: 15). Moreover, new business models shall be encouraged. Instead of embedding or restricting markets, the fictitious commodification of nature will continue. However, it was exactly this profit oriented system which has led to climate change as part of multiple crisis in the first place. The WBGU-approach of solving this crisis is based on the same rationality which caused it. Polanyi, to whom the Advisory Council also refers, has developed another vision - the vision of a society where nature, labour and money are withdrawn from the market sphere. He speaks about 'the end of the market economy' (Polanyi 1978: 339, own translation). His vision, therefore, is for a new social contract with a different kind of economy.

Some social movements today have already begun to develop alternative economies. For instance, the new commons movement which find expression in projects such as the urban gardening movement, the movement for energy-autonomous regions, the movement for a solidarity-based or social economy ${ }^{3}$. Here new economic rules are emerging that prioritise the common good instead of private property, cooperation instead of competition, or caring for others and supporting nature instead of maximising one's self-interested utility. Therefore, we interpret these movements again as an approach to small and concrete new social contracts.

Looking at the relationship between the political and the economic sphere, the German Advisory Council acknowledges that the whole social order is subject to economic principles such as cost-benefit analysis (WBGU 2011: 67, 68). The Advisory Council concludes that "The Great Transformation" needs a strong, organising and proactive state with extended participation' (ibid: 203f). This sounds almost Polanyian, but there are problematic and unquestioned assumptions. That there are signs that 'democracy' is in crisis receives some recognition, but democratisation is seen as an evolutionary process with a general trend worldwide towards it still in place (ibid: 51, 52). Yet, in mainstream debates, democratic culture and the political action associated with climate change are often framed in catastrophic terms and are overlaid by technocratic approaches to solutions (Brand 2011). While extreme meteorological events demand quick action, negotiation processes require time. Technological solutions, such as dams or water-conserving irrigation systems, appear to be easier to implement than socioecological solutions requiring that governments and society adopt different ways of thinking and acting. This is aggravated by the fact that climate change itself implies hazards for the political system and democracy. Emergency response plans and safety precautions may ultimately result in governments operating on the basis of an ongoing state of emergency. The judicial system could be suspended 'temporarily' during crises, in the interest of maintaining public order (see also Agamben 2004). Alarming in terms of both democratic theory and practice, is that governments consider a state of emergency as being the 'normal case' (ibid.). This would be further reinforced and consolidated by extreme events and by crises triggered by climate change. It is diametrically opposed to the intention of applying democratic principles to the design of physical and societal change. That is why medium- and long-term adaptation processes,

\footnotetext{
3 for an example from the south, see Rebel Seeds, South Africa https://www.facebook.com/rebelseedsavers/
} 
the selection of procedures to achieve them, and the design of strategies must all be scrutinised to determine whether and how they could counteract this potential deficit in democracy. The German Advisory Council on Global Change does not even mention this problem in the 2011 Flagship Report or the 2014 Special Report.

The WBGU's evolutionary perspective reinforces an idea of the state as 'promoting and demanding'. The concept of a proactive state includes an agenda 'from welfare to workfare' based on 'repressive inclusion', as we call it. This proactive and therefore more interventionist state as a 'new statehood' ideal of the Advisory Council 'must be offset by a "more" in citizen involvement in the form of a new social contract (...). The key aspect of this (virtual) contract is that it confers rights and obligations to government and civil society actors by giving them responsibility for the ecological future with a view to common welfare goals and global collective goods' (WBGU 2011: 204). But the WBGU does not reflect the participation trap. Often the realities of participation are such that participation is limited to getting stakeholders involved on an advisory or consultancy basis. The purpose here is not to design the decision-making processes, but rather to improve the solution of problems. The groups are consulted whenever their expertise is needed (in the interest of avoiding conflict and/or seeking compromise), and can be excluded just as easily (Walk 2008: 264). Participation of this type is called ,co-optation'. It is not undertaken with an eye toward those taking part. Rather, these participation processes are instrumentalized by the administration - to legitimise one's own actions, to justify outsourcing of public tasks where revenue is scarce, or hoping to work out an effective solution to the problem. Adaptation to accommodate climate change, however, requires high degrees of participation and democratic skills if adaptation and dealing with uncertainties is not to become authoritative and technocratic. This presents great challenges to the political arena and public administration, since players who had previously been privileged (political parties, administrative boards, interest associations, etc.) have to step back and rethink their accustomed positions. Government facilities will have to open themselves to the outside world and promote citizen participation from an institutional level. Only in that way can a level playing field be instituted where citizens can act both independently and with momentous consequences (Winterfeld 2014). The participation trap also means an instrumentalising inclusion. An inclusion which again 'forgets' the perspective of lifeworld, of care and of regeneration, because participation is managed as a business process which privileges corresponding actors (see also Ghorashi; Sabelis 2012).

On the contrary a contemporary powerful European movement is developing such that organisations from all over Europe are currently fighting for a European Citizens' Initiative against TTIP and CETA. These activities, again, can be interpreted as a contribution to a concrete new small social contract, because they call for new economic principles where democratic decisions are given priority over profit interests.

\section{Conclusion}

Rounding off the argument, we want to reemphasize our three domination principles: alienation and reification; dualism, separation and identification; instrumentalism and objectification.

From the perspective of alienation and reification we have to add that the critique of the egoistic self at the core of liberal individualism as well as the critique of instrumental reason formulated by Val Plumwood highlights a fundamental human alienation from 
nature. This alienation affects women as well as men. In addition, Carol Pateman has helped clarify another dimension of alienation for women; women are alienated from and part of the new political order of social contract because of the mechanism of separating inclusion. They are not only alienated from themselves by their economic but also by their political role.

Equality gains do not solve this problem. If women want to take part, they have to participate in the new market order which is an implicit part of the political order, as we showed based on Thomas Hobbes. Within his state of nature as a state of war, individuals are also fighting against each other because they compete for scarce goods. Hobbes's Leviathan does not undermine competition but guarantees suitable conditions (like safety) for the emerging market society. As argued, within a Hobbesian society, people are socially dispossessed and insular individuals with no social capabilities. They are reduced to an instrumental homo oeconomicus always looking for objects to satisfy his selfish wants and to enlarge his benefits - and add to the Other's disadvantages.

The economic order follows the principle and pattern of dualism, separation and identification (economy as identified only with separated markets and human actors only as owners of commodities). This principle of separation is still valid, while the boundaries between 'the intern' and 'the extern' are changing. The political order is in a defensive position. Globalisation of the economy and market result in the state becoming politically dependent on a dominant neoliberal order rather than advancing the interests of the state itself resulting in the intentional shrinking of the public sphere and growth of the private sphere. Empirically and with the advent of neoliberalism this is apparent in decreasing public goods and increasing private goods since the 1980s. Nevertheless, state interests are paramount in the development of security policy which is increasingly framed by discourses of the same and the other, of 'failed' and 'legitimate' states, of Foreign and Security Policy. It can also be formulated as highlighting the same and clouding or shadowing the other.

Our analysis of the reports from the German Advisory Council on Global Change shows that some of the debate around participation and citizen movement also tends to reproduce the domination principles of instrumentalism and objectification. A change in perspective is necessary. The old perspective is the perspective of the market, of the abstract rational individual, of those who have power. An alternative perspective is the perspective of life-world, of women and men in contexts, and of diversity. It is the perspective of the until now 'invisible'. This new perspective makes this invisible visible (O'Hara 2009:184 ff.), especially by new methodological principles of valuation. In the old perspective, valuation means to use 'objective' measures like GDP but this ignores the non-measurable aspects of economics of daily life outside the market. 'Instead, the acceptance of context is a vote for detailed empirical observation, historical awareness... This implies... the often invisible expertise of locals... the effective representation of situated agents...' (ibid: 189). 'Methods reflect power structure', writes Sabine 0'Hara (ibid: 187) and objectivity strengthens the structure of separation.

We conclude that if separating and instrumentalising inclusion and the sexual contract are still at work, as seems to be the case in WBGU's concept of social contract, and furthermore intensified by the new proactive state, there is no chance for real 
participation - and for a really new social contract. Relating to our three domination principles (alienation and reification; dualism, separation and identification; instrumentalism and objectification) we want to add another criterion of domination: the high level of abstraction and the absence of concrete individuals with concrete daily lives. If both are present, social movements and their struggle for emancipation become apparent as well.

And here we are back in sync with Nancy Fraser's (2011) and Val Plumwood's (1988) conclusions that a transformation towards a sustainable future needs the power of social movements against domination. It needs people who act in relation to concrete others and who essentially feel related to nature. We do not know whether, in the long run, a new social contract which fosters sustainability will emerge. But if it does surface, then it has to be based on multiple small and locally embedded concrete contracts which enable people to create their own sustainable relationships. 


\section{Bibliography}

Agamben, Giorgio (2004): Ausnahmezustand. Suhrkamp.

Atewologun, Doyin; Sealy, Ruth; Vinnicombe, Susan (2016): Revealing Intersectional Dynamics in Organizations: Introducing 'Intersectional Identity Work'. In: . Edited by: Jenny Rodriguez, Evangelina Holvino, Joyce K. Fletcher, Stella M. Nkomo. Gender, Work \& Organization, Volume 23, Issue 3, pp. 223-247

Bauriedl, Sybille (2015): Eurozentrische Weltbürgerbewegung. Zum WBGUSondergutachten Klimaschutz als Weltbürgerbewegung. GAIA 24/1: 13-16.

Bauriedl, Sybille; Wichterich, Christa (2014): Ökonomisierung von Natur, Raum, Körper. Rosa-Luxemburg-Stiftung Berlin (Ed.)

Biesecker, Adelheid; Breitenbach, Sarah; von Winterfeld, Uta (2016): Bürger ohne Eigenschaften? Die Weltbürgerbewegung gendersensibel verstehen. GAIA 25/3 (2016),pp. 152-155

Biesecker, Adelheid; von Winterfeld, Uta (2014): Extern? Weshalb und inwiefern moderne Gesellschaften Externalisierung brauchen und erzeugen. Expertise, gefördert von der Rosa-Luxemburg-Stiftung. Working Paper 2/2014 der DFG-

KollegforscherInnengruppe Postwachstumsgesellschaften. Jena (www.kollegpostwachstum.de)

Biesecker, Adelheid; von Winterfeld, Uta (2013): Alte Rationalitätsmuster und neue Beharrlichkeiten? Kritische Impulse zu blinden Flecken der Transformationsdebatte. In: GAIA 22/3 (2013), pp. 160-165

Brand, Ulrich (2011): Klimapolitik in Zeiten globaler Krisen. Alte und neue Konflikte. In: Politik im Klimawandel. Keine Macht für gerechte Lösungen? Herausgegeben von S. S. Schüttemeyer. Nomos, pp. 99-112

Brunnengräber, Achim (2014): Eine Weltbürgerbewegung ohne Realitätsbezug. Zum WBGU-Sondergutachten Klimaschutz als Weltbürgerbewegung. In: GAIA 23/4 (2014), pp. 306-308

Demirović, Alex; Dück, Julia; Becker, Florian; Bader, Pauline (Eds.) (2011): VielfachKrise im finanzmarktdominierten Kapitalismus. VSA

Ehrenreich, Barbara; Hochschild, Arlie (2002) Global Woman. Nannies, Maids and Sex Workers in the New Economy. Metropolitan Books, Holt Publishers

Fraser, Nancy (2012): Can Society be Commodities all the way down? Polanyian reflections on capitalist crisis. In: Fondation Maison des sciences de l'homme. Working papers Series Nr. 18, August 2012

Fraser, Nancy (2011): Marketization, Social Protection, Emancipation: Toward a NeoPolanyian Concept of Capitalist Crisis. In: Calhoun, Craig; Derluguian, Georgi (Hg.): Business as Usual. The Roots of the Global Financial Meltdown. New York University Press, pp. 137-157

Gorashi, Halleh; Sabelis, Ida (2012): Juggling difference and sameness: Rethinking strategies for diversity in organizations. In: Scandinavian Journal of Management (2012). http://www.sciencedirect.com/science/article/pii/S0956522112001352 (last accessed 18 august 2016) 
Hirschman, Albert O. (1991): The Rhetoric of Reaction. Cambridge MA.

Lang, Eva; Wintergerst, Theresia (2013): Das gute lange Leben. Wie unsere alternde Gesellschaft eine Zukunft haben kann. In: Netzwerk Vorsorgendes Wirtschaften (Ed.): Wege Vorsorgenden Wirtschaftens. Metropolis, pp. 349-384

Marx, Karl (1867/1972): Das Kapital Bd. 1, Dietz-Verlag

Narr, Wolf-Dieter (2015): Niemands-Herrschaft. Einführung in Schwierigkeiten, Herrschaft zu begreifen. Ed. By Uta v. Winterfeld. VSA

Nussbaum, Martha (2011): Creating Capabilities. The Human Development Approach. The Belknap Press of Harvard University Press

O'Hara, Sabine (2009): Feminist Ecological Economics in Theory and Practice. In: Salleh, Ariel (Ed.): Eco-Sufficiency \& Global Justice. Women write Political Ecology. Pluto Press, pp. $180-196$

Pateman, Carole (1988): The Sexual Contract. Stanford University Press

Plumwood, Val (1991): Nature, Self, and Gender: Feminism, Environmental Philosophy, and the Critique of Rationalism. In: Hypathia. Vol. 6, No. 1, Ecological Feminism (Spring, 1991), pp. 3-27

Plumwood, Val (2002): Environmental Culture: the Ecological Crisis of Reason. Routledge

Polanyi, Karl (1944/1978): The Great Transformation. Politische und ökonomische Ursprünge von Gesellschaften und Wirtschaftssystemen. Suhrkamp

Reitzig, Jörg 2005: Gesellschaftsvertrag, Gerechtigkeit, Arbeit. Eine hegemonietheoretische Analyse zur Debatte um einen „Neuen Gesellschaftsvertrag“ im postfordistischen Kapitalismus. Westfälisches Dampfboot

Tronto, Joan C. (2013): Caring Democracy. Markets, Equality, and Justice. New York University Press

Unmüßig, Barbara (2015): Die Rolle der Zivilgesellschaft in der Klimapolitik. GAIA 24/3: 160-163.

Walk, Heike (2008): Partizipative Governance. Beteiligungsformen und Beteiligungsrechte im Mehrebenensystem der Klimapolitik. VS-Verlag

Wallraff, Günter (Ed.) (2014): Die Lastenträger. Arbeit im freien Fall - flexibel schuften ohne Perspektive. Kiepenheuer \& Witsch

WBGU (German Advisory Council on Global Change) (2014): Climate Protection as a World Citizen Movement. Special Report. Berlin

WBGU (2011): World in Transition A Social Contract for Sustainability. Flagship Report. Berlin

Wichterich, Christa (2011): Krise der Ernährermännlichkeit und neoliberale Gleichstellung durch die Krise. In: Demirovic, Alex et al., op.cit., pp 129-145

Winterfeld, Uta von (2014): Participation is not sufficient. Climate change and a democratic culture. In: Grit Martinez; Peter Fröhle; Hans-Joachim Meier (Eds.) (2014): 
Social Dimensions of Climate Change Adaptation in Coastal Regions. Findings from Transdisciplinary Research. oekom, pp. 175-189

Winterfeld, Uta von; Biesecker Adelheid (2013): Es geht nicht allein. Vorsorgendes Wirtschaften braucht neue Gesellschaftsverträge. In: Netzwerk Vorsorgendes Wirtschaften (Ed.): Wege Vorsorgenden Wirtschaftens. Metropolis, pp. 385-401 